\title{
Relations between China's Foreign Direct Investment and Trade with Brazil
}

\author{
Ya-Nan Song \\ School of Business Macau University of Science and Technology Taipa, Macau \\ Institute for Social and Cultural Research Macau University of Science and Technology Taipa, Macau \\ ynsong@must.edu.mo
}

\begin{abstract}
As the emerging economies and major developing members of WTO, the bilateral trade of China and Brazil has grown robustly over the past few years, although with the conflicts on trade frictions and anti-dumping issues. The foreign direct investment from China to Brazil has also increased rapidly under the effect of kinds of factors. The aims of this paper are to examine the causal relationship between China's outflow foreign direct investment (OFDI) and trade (imports and exports) to Brazil, and to find out whether exports from China are complements or substitute to the FDI in Brazil. The results indicate the growth of China's imports of primary products and exports of manufactured products cause the growth on OFDI to Brazil significantly, while the OFDI to Brazil shows no significant causes on China-Brazil bilateral trade values.
\end{abstract}

Index Terms - OFDI, Bilateral Trade, VEC Model, Primary Products, Manufactured Products

\section{Introduction}

As noted by the United Nations Conference on Trade and Development (1996), conceptual models of foreign direct investment (FDI) and international trade have traditionally been developed separately. The possible linkages between FDI and international trade have been widely documented. Are FDI and trade substitutes or complements? Are there any causal relations between FDI and trade? An understanding of these linkages helps governments harmonize their FDI and trade policies for growth and development.

In terms of FDI-trade relations, China-Brazil bilateral economic relationship is rapidly deepening. China and Brazil both now play an increasingly important role in the global economy. In 1993 China recognized Brazil as a "Strategic Partner", the first Latin American country to receive this designation. In 2010 China was Brazil's largest trading partner, accounting for over 15 per cent of total Brazilian exports and supplying over 14 per cent of its imports. Brazil has become a major supplier of iron ore and soy-beans to the Chinese market, and exports to China increased almost thirtyfold between 2000 and 2010. Although on nothing like the scale of trade, China is becoming an increasingly large source country of FDI in Brazil.

The aims of this paper are to examine the causal relationship between foreign direct investment (FDI) and trade (imports and exports) under the perspective of China-Brazil interactions, and to find out whether exports from China are complements or substitute to the FDI in Brazil. Section 1 of this paper will introduce the overall situations of China-Brazil trade and FDI relations, and the literature reviews of existed theoretical and the empirical linkage between FDI and foreign trade. The data and methodology are described in Section 2 by using Vector Error Correction (VEC) Model and Granger Causality Test based on bilateral data for China and Brazil from 1987 to 2013. The results will be discussed in Section 3, and Section 4 provides conclusions and implications.

\section{Literature review}

\section{A. Theoretical considerations}

In the international economics and business literature, Researchers studied whether FDI is a substitute for, or a complement to, international trade. The Heckscher-OhlinSamuelson model suggests that international trade can substitute for international movement of factors of production including FDI. This model implies that international commodity trade involves an indirect exchange of factors between countries. For instance, by exporting capital-intensive commodities in exchange for labour-intensive commodities, the capital-abundant country indirectly exports a net amount of capital in exchange for a net amount of labour. Even under the assumption that factors are perfectly immobile between countries, factors do migrate between countries indirectly through exports and imports of commodities. Helpman (1984) and Helpman and Krugman (1985) illustrate that the degree of specialisation is a positive function of relative factor endowments [1-2]. If differences in factor endowments are not substantial, a capital-abundant country will produce capitalintensive differentiated goods at home and exchange them for the labour-intensive homogeneous good from a labour-abundant country. Thus, FDI generates complementary trade flows from the labour-intensive country. In addition, parent firms may export intermediate inputs to their subsidiaries if vertical integration is involved. As noted by Markusen and Maskus (1999), the model developed by Helpman captures the notion of vertically integrated firms but does not allow FDI to happen between very similar countries [3].

Brainard (1993), Horstman and Markusen (1992) develop a model that distinguishes between plant- and firm-level scale economies and acknowledges the existence of trade barriers such as tariffs and transport costs [4-5]. They think that the choice between horizontal FDI and international trade at both firm and country levels depends on the trade-off between proximity and concentration. If proximity advantages outweigh concentration advantages, there will be more FDI instead of trade. Therefore, there can be a substitution relationship between FDI and trade. Markusen and Venables $(1996,1998)$ introduce countries' asymmetries in explaining 
the choice between international trade and FDI based on countries differing in relative endowments [6-7]. For convenience, firms tend to be national and located in the advantaged countries. As the disadvantaged country develops in terms of local market size, factor endowments, and technological efficiency, more and more firms from the advantaged country will establish subsidiaries in the disadvantaged country. Thus, FDI and trade can exist simultaneously. Brainard (1997) also suggests that multinational activity is more likely the more similar are the home and foreign markets, that multinational production will substitute for trade when countries are similar [8].

In terms of causality, the existing literature shows that many firms in manufacturing still follow the traditional stepby-step sequence of servicing foreign markets. After learning more about the economic, political, and social conditions and gaining more experience, home country firms may establish producing subsidiaries in the foreign market. While foreign subsidiaries may begin to export (Johanson \& Wiedersheim, 1993) finally [9]. So there can be a two-way causal link: trade will first cause FDI and FDI may eventually cause trade, which consistent with Vernon's (1966) product cycle hypothesis [10].

\section{B. Empirical evidence}

Existing empirical studies use different data and estimation techniques and the results are mixed. Lipsey and Weiss (1984) estimate trade and affiliate productions using cross-sectional firm-level data and find a positive relationship between US firms' outputs in a foreign area and the firms' exports from the United States to that area [11]. Using trade equations and US and Swedish firm-level data, Blomstrom, Lipsey, and Kulchycky (1988) find that the relationship between FDI and export sales is complementary [12]. Pfaffermayr (1996) argues that outward FDI and exports can have common determinants such as capital, labour, skill, and R\&D intensities [13]. Using bilateral data for Japan and its 20 major trading partners for the period 1982-1995, Bayoumi and Lipworth (1997) regress trade flows on the stock and flow of FDI from Japan, aggregate demand in foreign (home) market and relative prices between the export and import markets. They conclude that outward FDI from Japan has a temporary impact on exports but a permanent effect on imports [14].

Using an augmented export demand model and a panel data set at the economy level for 11 OECD countries for the period 1971-1992, Pain and Wakelin (1998) find evidence of heterogeneity in the relationships between FDI and exports [15]. The outward FDI has a negative impact on trade shares, while inward FDI has a positive one. Wang and Zhu (2004) also find evidence on FDI encouraging the bilateral trade by using panel data from China and ASEAN countries [16].

And some attention has been paid to the substitutioncomplement relationships, explicit testing for causality between FDI and trade is extremely rare. Xiang (2003) estimates the international trade and FDI relations in various times and find that FDI is substitute to trade in China before 1980s', while is complementary after that [17].

\section{Data and methodology}

A. Methodology

Based on the above studies, this paper will examine the causal relationship between foreign direct investment (FDI) and trade (imports and exports) under the perspective of China-Brazil interactions, and to find out whether exports from China are complements or substitute to the FDI in Brazil by estimating the following VAR model. In order to deepen the research, this paper describe the exports from China to Brazil as primary exports and manufactured products exports.

A VAR model describes the evolution of a set of $\mathrm{k}$ variables (endogenous variables) over the same sample period $(\mathrm{t}=1, \ldots, \mathrm{T})$ as a linear function of only their past evolution. The variables are collected in a $\mathrm{k} \times 1$ vector $y_{t}$, which has as the ith element $y_{i}$.

A (reduced) p-th order VAR, denoted $\operatorname{VAR}(\mathrm{p})$, is

$$
y_{t}=c+\phi_{1} y_{t-1}+\cdots+\phi_{p} y_{t-p}+\varepsilon_{t}
$$

where $\mathrm{c}$ is a $\mathrm{k} \times 1$ vector of constants (intercept), ${ }^{\phi_{i}}$ is a $\mathrm{k} \times \mathrm{k}$ matrix(for every $\mathrm{i}=1, \ldots, \mathrm{p}$ ) and ${ }^{\varepsilon_{t}}$ is a $\mathrm{k} \times 1$ vector of error terms.

This paper analyzes 5 relations between OFDI and bilateral trade flows, so the VAR models for estimating the relations of FDI and trade between China and Brazil go as

$$
\begin{aligned}
& {\left[\begin{array}{c}
\ln O F D I_{t} \\
\ln I M C_{t} \\
\ln I M G_{t} \\
\ln E X C_{t} \\
\ln E X G_{t}
\end{array}\right]=c_{1}+\sum_{j}^{p} \beta_{j} \ln O F D I_{(t-j)}+\sum_{j}^{r} \varphi_{j} \ln I M C_{(t-j)}+\sum_{j}^{r} \varphi_{j} \ln I M G_{(t-j)}} \\
& +\sum_{j}^{q} \varphi_{j} \ln E X C_{(t-j)}+\sum_{j}^{n} \varphi_{j} \ln E X G_{(t-j)}+\varepsilon_{i t}
\end{aligned}
$$

Where OFDI is the value of China's outflow FDI to Brazil; IMC is the value of China's import of primary products from Brazil; IMG is the value of China's import of manufactured products from Brazil; EXC is the value of China's export of primary products to Brazil; EXG is the value of China's export of manufactured products to Brazil; $p$, $\mathrm{r}, \mathrm{q}$ and $\mathrm{n}$ indicate the lag period.

\section{B. Data}

The data set of this study consists of yearly observations covering the period from 1987 to 2013 . OFDI is the logarithm of the value of China's outflow FDI to Brazil; IMC is the logarithm of the value of China's import of primary products from Brazil; IMG is the logarithm of the value of China's import of manufactured products from Brazil; EXC is the logarithm of the value of China's export of primary products to Brazil; EXG is the logarithm of the value of China's export of manufactured products to Brazil. All the data collect from UNCTAD database.

\section{Unite Root Tests and VAR Lag Order Selection}

This paper couches the model in logarithmic difference form to induce stationarity. The legitimacy of this is 
establishing using Augmented Dickey-Fuller test (ADF). The results are presented in Table 1 and they confirm that the log changes are all without intercept and trend. The test statistic of ADF are compared with critical values given in MacKinnon (1991). To ensure that disturbance variables in all these equations are white noise, a sufficient number of lagged differences or truncated lag, have been estimated using Akaike Information Criteria (AIC)

TABLE 1 ADF Sequence Stationary Testing

\begin{tabular}{|c|c|c|c|c|c|}
\hline- & ADF Statistics & P Value & Variable & ADF Statistics & P Value \\
\hline OFDI & -0.230 & 0.988 & DOFDI & -7.430 & $0.00^{*}$ \\
\hline IMC & -2.744 & 0.228 & DIMC & -4.660 & $0.00^{*}$ \\
\hline IMG & -3.449 & 0.067 & DIMG & -4.797 & $0.00^{*}$ \\
\hline EXC & -3.075 & 0.134 & DEXC & -4.317 & $0.01^{*}$ \\
\hline EXG & -2.383 & 0.378 & DEXG & -5.160 & $0.00^{*}$ \\
\hline
\end{tabular}

Note:D denotes first difference; * indicate significant at the $1 \%$ level

Unit root tests on the first difference of all series show the rejection of null hypothesis in 1 level form in the autoregression representation of each variables, that means they are all I(1). Furthermore, the choice of lag lengths, 3, for the VAR is chosen on the basis of several statistical criteria.

\section{Johansen-Juselius Cointegration Test}

The cointegration level determined by ADF and PP tests allows us to check for the existence of the long run relationship between our variables using the cointegration test. It consists of checking the cointegration relation among variables while avoiding spurious results in case data are nonstationary. One of the main advantages of the Johansen and Juselius (1990) maximum likelihood method over other cointegration tests is that it can check for more than one existing cointegrating (i.e. long run) relationships among the variables. If the cointegration analysis indicates that there is a cointegrating vector, we infer that the tested series will not drift apart in the longterm, and will revert to equilibrium levels following any short-term drift that may take place. In the context of this study, the null hypothesis is that no cointegration relation exists and rejecting the null allows us to infer that both indicators are interrelated with each other in the long run.

TABLE II Johansen-Juselius Cointegration Test

\begin{tabular}{|c|c|c|c|c|c|}
\hline $\begin{array}{c}\text { No. of } \\
\text { CE(s) }\end{array}$ & EigenValue & $\begin{array}{c}\text { Trace } \\
\text { Statistic }\end{array}$ & P Value & $\begin{array}{c}\text { Max-Eigen } \\
\text { Statistic }\end{array}$ & P Value \\
\hline None & 0.997 & 220.838 & $0.000^{*}$ & 136.947 & $0.000^{*}$ \\
\hline At most 1 & 0.835 & 83.890 & $0.000^{*}$ & 41.5564 & $0.000^{*}$ \\
\hline At most 2 & 0.686 & 42.334 & $0.001^{*}$ & 26.706 & $0.007^{*}$ \\
\hline At most 3 & 0.421 & 15.628 & $0.047^{*}$ & 12.582 & 0.090 \\
\hline At most 4 & 0.1240 & 3.045 & 0.081 & 3.0455 & 0.081 \\
\hline
\end{tabular}

Note:* indicate significant at the $1 \%$ level
Table II shows there are three cointegration relations exists between OFDI and bilateral trade variables. The coefficients of regressions are statistically significant at 5 percentages, and the regression models pass the general significance test. And every models' inverted roots of the lag polynomial lie inside the unit circle, denoting the stationarity condition for general AR processes.

\section{Empirical Analysis}

\section{A. VECM Results}

Table III shows the coefficients in the cointegrating equation give the estimated long run relationship among the variables, whereas the coefficient of the error correction term ecm in the VECM estimation shows how deviations from the long run equilibrium affect changes in the variable in the next year; the other coefficients provide estimation of short run association between the FDI outflows of China to Brazil and trade variables of different products.

Table III Vector Error Correction Model Estimation Results

\begin{tabular}{|c|c|c|c|c|c|}
\hline & $\begin{array}{c}\text { Model I } \\
\text { OFDI }\end{array}$ & $\begin{array}{c}\text { Model II } \\
\text { IMC }\end{array}$ & $\begin{array}{c}\text { Model III } \\
\text { IMG }\end{array}$ & $\begin{array}{c}\text { Model IV } \\
\text { EXC }\end{array}$ & $\begin{array}{c}\text { Model V } \\
\text { EXG }\end{array}$ \\
\hline ecm(-1) & -0.02 & -0.06 & -1.01 & 0.32 & 0.19 \\
\hline OFDI(-1) & -0.34 & 0.07 & 0.06 & -0.02 & 0.04 \\
\hline OFDI(-2) & 0.14 & 0.00 & 0.03 & -0.07 & 0.02 \\
\hline IMC(-1) & $0.04^{*}$ & -0.28 & -0.14 & 0.12 & $0.71^{* *}$ \\
\hline IMC(-2) & $1.98^{*}$ & -0.24 & $0.54^{* *}$ & -0.20 & -0.02 \\
\hline IMG(-1) & 1.86 & -0.13 & $0.45^{*}$ & $0.51^{*}$ & -0.03 \\
\hline IMG(-2) & -1.05 & -0.28 & $-0.76^{* *}$ & 0.33 & 0.16 \\
\hline EXC(-1) & 0.89 & 0.66 & 0.41 & -0.22 & -0.16 \\
\hline EXC(-2) & -1.32 & 0.15 & 0.04 & -0.25 & -0.17 \\
\hline EXG(-1) & -2.39 & 0.10 & $-1.10^{* *}$ & -0.31 & -0.17 \\
\hline EXG(-2) & $2.99 * *$ & 0.20 & $0.46^{*}$ & $-0.63^{*}$ & -0.06 \\
\hline C & -0.06 & 0.22 & 0.17 & $0.52^{* *}$ & 0.17 \\
\hline R2 & 0.62 & 0.22 & 0.85 & 0.72 & 0.75 \\
\hline Adj. R2 & 0.23 & -0.56 & 0.70 & 0.44 & 0.49 \\
\hline F-statistic & 1.60 & 0.29 & 5.62 & 2.57 & 2.92 \\
\hline AIC & 3.89 & 2.02 & 0.02 & 0.45 & 0.22 \\
\hline SC & 4.48 & 2.61 & 0.62 & 1.04 & 0.82 \\
\hline
\end{tabular}

Note: a *,** indicate significant at the $5 \%$ and $1 \%$ level. $b$ all variables are in logs and first difference.

Model I shows a positive short run association appears to exist between the FDI outflow of China to Brazil and the import of primary products from Brazil. An increase of import of primary products from Brazil by $1 \%$ causes FDI outflow increase by $0.04 \%$ from China to Brazil at $5 \%$ significant level. And an increase of export of manufactured products from Brazil by $1 \%$ causes FDI outflow increase by $2.99 \%$ from China to Brazil at $1 \%$ significant level. This shows manufactured products exports of China have more important effects on promoting the FDI in Brazil from China, by China's manufacturers exploring the Brazilian market with export 
those manufactured products which China have more comparative advantages, then making foreign direct investment as an escalating strategy for entering Brazilian markets.

Although the trade promotes the FDI outflow from China to Brazil, there still no significant evidence can show the outflow FDI of China also increase the bilateral trade flows between China and Brazil.

\section{B. Granger Test Results}

To examine the causal relationships and directions of causality between the OFDI and trade flows, this paper also run the Granger causality tests. It is important to notice that Granger causality is not necessarily a traditional causality; if both $\mathrm{X}$ and $\mathrm{Y}$ are driven by a third process, one would still reject the null hypothesis of Granger-causality. Based on a VEC model, a maximum lag of 2 is selected according to the likelihood ratio (LR), final prediction error (FPE), Akaike's information criterion (AIC) .

The results of Granger-causality tests estimated based on stationary series as presented in Table 5 confirm the finding in VEC model (Table III). No evidence is found of Grangercausality from the trade flows to the FDI outflows from China in any of the four models; nevertheless, IMC does Grangercause OFDI at the 5\% significance level, and in the same manner, the EXG does Granger-cause OFDI at 1\% statistical significance.

Table IV Granger-Causality Test Results

\begin{tabular}{|c|l|c|c|c|c|c|}
\hline $\begin{array}{c}\text { Granger } \\
\text { Reason }\end{array}$ & $\begin{array}{c}\text { Granger } \\
\text { Result }\end{array}$ & OFDI & IMC & IMG & EXC & EXG \\
\hline OFDI & Chi-sq & -- & 0.377 & 2.500 & 1.863 & 0.771 \\
\hline IMC & Chi-sq & $3.132 *$ & -- & $8.25^{* *}$ & 1.036 & $8.25 * *$ \\
\hline IMG & Chi-sq & 2.253 & 0.226 & -- & 3.440 & 0.518 \\
\hline EXC & Chi-sq & 1.002 & 0.392 & 1.040 & -- & 0.537 \\
\hline EXG & Chi-sq & $5.764 *$ & 0.073 & $22.2 * *$ & 3.523 & -- \\
\hline
\end{tabular}

Note: All variables are in logs and first difference.

\section{Conclusion}

This paper investigated the inter-linkage between Foreign Direct Investment from China to Brazil and bilateral trade flows by using yearly observations and different proxies that measure the bilateral trade flow structure by primary products and manufactured products. The results of the JohansenJuselius cointegration test present evidence of a long run relationship between foreign direct investment from China to Brazil and bilateral trade flows. As far as the result of the VECM are concerned, none of the coefficients of the short run regressions in all three models are significant, which implies that there is no evidence of a year-to-year influence of the bilateral trade flows on the outflow FDI of China to Brazil. Whereas, the import of primary products from Brazil positively impact the China's FDI in Brazil slightly. And an increase of export of manufactured products from China also positively impact China's FDI in Brazil significantly after two years later. The Granger Causality tests also prove the findings. These finding may be explained by the fact that China's manufacturers exploring the Brazilian market with export those manufactured products which China have more comparative advantages, then making foreign direct investment as an escalating strategy for entering Brazilian markets. Accordingly, the increase of import and export of products from China and Brazil promoting the FDI in Brazil shows the complementary relations between OFDI of China to Brazil and bilateral trade. These results also indicate the investment pattern between China and Brazil belongs to vertical investment which is resources-seeking or marketseeking investment for China. And with the development of Brazil economy and technology, horizontal investment should be developed between China and Brazil to cooperate in manufacturing products and technology development.

\section{Reference}

[1] Helpman, E. (1984). A simple theory of international trade with multinational corporations. Journal of Political Economy, 92 (3), 451471.

[2] Helpman, E., \& Krugman, P. R. (1985). Market structure and foreign trade. Cambridge: MIT Press.

[3] Markusen, J. R., \& Maskus, K. E. (1999). Multinational firms: reconciling theory and evidence (NBER Working Paper 7163).

[4] Brainard, S. L. (1993). A simple theory of multinational corporations and trade with a trade-off between proximity and concentration (NBER Working Paper no. 4269).

[5] Horstman, I., \& Markusen, J. R. (1992). Endogenous market structures in international trade. Journal of Internationa Economics, 20, 225-247.

[6] Markusen, J. R., \& Venables, A. J. (1996). The increased importance of direct investment in North Atlantic economic relationships: a convergence hypothesis. In: M. W. Canzoneri, W. J. Ethier, \& V. Grilli (Eds.), The new transatlantic economy (pp. 169-189) Cambridge Univ. Press.

[7] Markusen, J. R., \& Venables, A. J. (1998). Multinational firms and the new trade theory. Journal of International Economics, 46, 183-203.

[8] Brainard, S. L. (1997). An empirical assessment of the proximityconcentration trade-off between multinational sales and trade. American Economic Review, 87 (4), 520-544.

[9] Johanson, J., \& Wiedersheim, P. F. (1993). The internationalisation of the firms - four Swedish cases. In: P. J. Ghauri, \& P. Ghauri (Eds.), The internationalisation of the firm. London: Academic Press.

[10]Vernon, R. (1966). International investment and international trade in the product cycle. Quarterly Journal of Economics, 80, 190-207.

[11]Lipsey, R.E., \& Weiss, M.Y. (1984). Foreign production and exports of individual firms. Review of Economics and Statistics, 66, 304-308.

[12]Blomstrom, M., Lipsey, R. E., \& Kulchycky, K. (1988). US and Swedish direct investment and exports. In: R. E.

[13]Pfaffermayr, M. (1996). Foreign outward direct investment and exports in Austrian manufacturing: substitutes or complements? Weltwirtschaftliches Archiv, 132 (3), 501-552.

[14]Bayoumi, T., \& Lipworth, G. (1997). Japanese foreign direct investment and regional trade (IMF Working Paper WP/97/103). IMF.

[15]Pain, N., \& Wakelin, K. (1998). Export performance and the role of foreign direct investment. Manchester School (N. SS, 66), 62-88.

[16]Wang and Zhu (2004). The Impact of ASEAN Direct Investment on China-ASEAN Trade. Inquiry into Economic Problems, 2004, 12, 11-14.

[17]Xiang (2003). China's Empirical Study of Relations between International Trade and FDI. World Economy Study, 2003, 03, 14-19. 